\title{
PERSEPSI MUBALIGH DAN MUBALIGHAH TERHADAP KESETARAAN DAN KEADILAN GENDER DI KOTA MEDAN
}

\author{
Dahlia Lubis \\ Fakultas Ushuluddin dan Studi Islam UIN Sumatera Utara \\ Jl. Willem Iskandar Pasar V Medan Estate, Sumatera Utara, 20371 \\ e-mail: dahlia_iain@yahoo.com
}

\begin{abstract}
Abstrak: Penelitian ini bertujuan untuk melihat persepsi mubaligh dan mubalighah di Kota Medan terhadap kesetaraan dan keadilan gender. Penelitian ini bersifat kuantitatif dan dilakukan pada lima kecamatan di pinggiran kota Medan, yakni Medan Tembung, Medan Amplas, Medan Tuntungan, Medan Sunggal dan Medan Marelan. Penelitian ini menyimpulkan bahwa persepsi muballigh dan mubalighah terhadap keadilan dan kesetaraan gender belum belum konsisten. Ada kesadaran gender pada satu tema di dalam satu indikator, tapi tidak sejalan dengan tema lain dalam indikator yang sama, sehingga muncul pendapat yang kontra. Mayoritas mereka setuju bahwa pemimpin tidak harus laki-laki, tapi mereka tidak setuju bila perempuan menduduki jabatan lebih tinggi dari laki-laki. Selain itu, jenis kelamin perempuan lebih cenderung menunjukkan keberpihakannya kepada perempuan, sedangkan dari pihak laki-laki 50\% masih menunjukkan bias gender.
\end{abstract}

\begin{abstract}
The Perception Muslim Male and Female Preacher on Gender Equity and Justice in Medan. This research aims to find out the perception of gender equity and justice among preachers in North Sumatra province in the suburban of Medan, namely; Tembung, Amplas, Tuntungan, Sunggal and Medan Marelan. The author concluded that the perception of preachers to justice and gender equality has not been entirely appropriate. There is incorrect understanding to religious creed which raises wrong perception to the gender equity and justice in matters of religious teachings. On one hand, they tend to to impress the gender awareness on one of theme in one of indicator that was not consistent with other themes that exist in the same indicators. Thus, counter argument appears, for example the majority of them agree that a leader should not be a man, but they also do not agree that a woman having higher positions than men. There is relationship between preachers perception with disposition of genders which woman like to show her side while the men from $50 \%$ still show gender bias.
\end{abstract}

Kata Kunci: gender, kesetaraan, keadilan, muballigh, muballighah 


\section{Pendahuluan}

Masalah gender telah lama menjadi perbincangan dalam berbagai kegiatan, mulai dari kajian keilmuan berupa training, seminar, workshop, atau diskusi-diskusi, juga penelitian sampai kegiatan yang bersifat nyata di lapangan. Namun, faktanya kesetaraan dan keadilan gender yang diperjuangkan, di kalangan masyarakat baik di kota maupun di desa termasuk di pinggiran kota, masih menjadi wacana, bahkan targetnya masih belum mencapai sasaran. Kesetaraan dan keadilan gender belum sepenuhnya terwujud, di mana masih banyak permasalahan gender yang dirasakan sebagai akibat kesenjangan gender. Kaum perempuan masih tertinggal dengan laki-laki dalam berbagai bidang. Untuk itu, perlu dilakukan upaya pemberdayaan perempuan yang didukung oleh berbagai pihak.

Mubaligh dan Mubalighah adalah salah satu ujung tombak panutan masyarakat yang memiliki potensi untuk turut serta dalam memberdayakan perempuan dan mensosialisasikan kesetaraan keadilan gender. Mubaligh dan Mubalighah juga berfungsi memberi pesan yang signifikan dalam ajaran agama bagi masyarakat. Ucapan dan perilaku Mubaligh dan Mubalighah adalah contoh bagi masyarakat yang sering didengar dan ditiru. Penafsiran terhadap ajaran agama yang disampaikannya adalah pengajaran yang diterima begitu saja oleh masyarakat. Penafsiran terhadap agama dianggap sebagai salah satu hambatan dalam menanamkan kesadaran kesetaraan dan keadilan gender.

Pokok permasalahannya adalah apakah Mubaligh dan Mubalighah itu sendiri memahami tentang apa dan bagaimana kesetaraan dan keadilan gender? Bagaimana persepsi mereka tentang kesetaraan dan keadilan gender? Apakah persepsi mereka tentang kesetaraan dan keadilan gender tidak keliru? Juga apakah persepsi mereka tentang keadilan dan kesetaraan gender telah membentuk sikap dan perilaku yang akan memengaruhi cara berpikirnya sehingga transformasi materi ceramah bernuansa kesetaraan dan keadilan gender. Permasalahan lebih lanjut memunculkan pertanyaan apakah para Mubaligh dan Mubalighah memiliki persepsi yang sama tentang keadilan dan kesetaraan gender ini berdasarkan jenis kelaminnya.

Kekeliruan persepsi terhadap peran gender akan menimbulkan sikap yang kontra terhadap kesetaraan dan keadilan gender. Dengan kekeliruan ini pun, transfer informasi tentang pemahaman ajaran agama yang disampaikan oleh Muballigh dan Mubalighah juga bisa disalahtafsirkan sehingga pada gilirannya akan menjadi salah dalam pemahaman dan penerapan oleh mereka yang mendengarkan. Melalui persepsi Mubaligh dan Mubalighah ini, transformasi yang dilakukannya akan banyak membawa pengaruh kepada individuindividu, keluarga, masyarakat dan negara.

Penelitian yang akan dilakukan terhadap Mubaligh dan Mubalighah ini sangat penting dan menarik untuk dikaji karena Mubaligh dan Mubalighah, khususnya, sebagai corong yang mentransfer pengetahuan agama kepada masyarakat secara langsung apakah memiliki persepsi yang tidak keliru tentang keadilan dan kesetaraan gender, apalagi Mubaligh 
dan Mubalighah sering dianggap mempunyai integritas sosial keagamaan. Dengan demikian, mereka mempunyai kondisi yang kondusif dalam kehidupan masyarakatnya dan lebih memiliki peluang besar untuk mentranformasikan dan mensosialisasikan gagasan-gagasan baru ke dalam tubuh masyarakat, dalam hal ini gagasan-gagasan tentang peran gender yang setara dan adil.

Pinggiran kota Medan juga menarik untuk menjadi perhatian dalam penelitian. Pinggiran Kota Medan sebagai wilayah yang berbatasan langsung dengan desa-desa di kabupaten/kota lain dapat dikatakan sebagai daerah transisi, di mana kondisi dan situasinya berada di antara desa dan kota. Di mana kondisi transisi ini belum terdukung dengan tingkat kesadaran akan sumber daya manusia pada umumnya dan kesadaran akan hakhak perempuan pada khususnya. Terlebih lagi keseimbangan peran laki-laki dan perempuan belum terwujud sebagaimana idealnya keadilan dan kesetaraan gender yang diperjuangkan selama ini.

Secara khusus, artikel ini membahas persepsi Mubaligh dan Mubalighah terhadap kesetaraan dan keadilan gender berdasarkan jenis kelamin. Perbedaan jenis kelamin biasanya memengaruhi persepsi seseorang yang pada dasamya merupakan bentukan dari pendidikan dan latar belakang budaya. Pendidikan akan membentuk pengalaman dan membentuk seseorang melalui pengetahuan dan ilmu yang ditransfer kepadanya, juga melalui lingkungan sekolah baik dari teman-teman atau guru-guru. Sedangkan budaya/suku memiliki peradaban atau bentukan adat yang dipertahankan secara turun-temurun sekaligus mencirikan diri sebagai stereotipe yang sebenarnya adalah konsumsi sosial semata. Dengan demikian, pemilihan tiga batasan di atas diharapkan dapat mewakili faktor-faktor yang memengaruhi persepsi Mubaligh dan Mubalighah di pinggiran kota Medan yang menjadi responden dalam kajian ini.

Mengenai makna persepsi dalam kajian ini adalah makna persepsi dalam kajian psikologi. Dalam kamus Psikologi, persepsi adalah "the process of recognizing or identifing something, usually employed of sense perception, when the thing which we recognize or identify is the object affecting a sense organ." Persepsi ialah proses mengenali atau mengidentifikasi sesuatu, biasanya menggunakan indera ketika sesuatu yang dikenali itu adalah benda yang dipengaruhi oleh indera. Sedangkan dalam bahasa Indonesia, persepsi ialah pandangan dari seorang atau banyak orang akan hal atau peristiwa yang didapat atau diterima; dan proses diketahuinya suatu hal pada seseorang melalui panca indera yang dimiliki. ${ }^{2}$ Persepsi dalam sumber yang lain juga diartikan dalam beberapa pengertian, ${ }^{3}$ proses mengetahui

${ }^{1}$ James Drever, A Dictionary of Psychology (England: Penguin Books, 1974), h. 206.

${ }^{2}$ Peter Salim dan Yenni Salim, Kamus Bahasa Indonesia Kontemporer (Jakarta: Modern English Press, t.t.), h. 1146.

${ }^{3}$ C.P. Chaplin, Kamus Lengkap Psikologi, terj. Kartini Kartono (Jakarta: RajaGrafindo Persada, 1981), h. 35; Sarlito Wirawan Sarwono, Pengantar Umum Psikologi (Jakarta: Bulan Bintang, 1982), 67. 
atau mengenali objek dan kejadian objektif dengan bantuan indera; kesadaran dari proses organis; satu kelompok penginderaan dengan penambahan arti yang berasal dari pengalaman di masa lalu; variabel yang ikut campur dalam melakukan pembedaan-pembedaan; keadaan intuitif mengenai kebenaran langsung atau keyakinan yang serta merta mengenai sesuatu.

\section{Teori Dasar tentang Gender}

\section{Pengertian Gender}

Istilah gender yang pertama muncul di kamus adalah penggolongan gramatikal terhadap kata-kata benda dan kata-kata lain yang berkaitan, yang secara garis besar berhubungan dengan jenis kelamin atau ketiadaan jenis kelamin. ${ }^{4}$ Gender berbeda dengan jenis kelamin. Jenis kelamin merujuk kepada makna perbedaan antara perempuan dan laki-laki dari ciri fisik biologis. Contoh perbedaan jenis kelamin antara perempuan dan laki-laki antara lain perempuan memiliki payudara, sedangkan laki-laki memiliki jakun, atau perempuan memiliki alat reproduksi yang berbeda dari laki-laki. Sedangkan gender merujuk kepada makna perbedaan antara perempuan dan laki-laki dalam peran fungsi dan tanggungjawab yang dikonstruksikan oleh tata nilai sosial dan budaya tertentu dan pada waktu tertentu.

Perbedaan jenis kelamin dan gender ini dapat dilihat dari sisi lain. Jenis kelamin merupakan ciptaan Tuhan, sedangkan gender adalah buatan manusia. Jenis kelamin bersifat kodrati, sedangkan gender bersifat non kodrat. Jenis kelamin tidak dapat berubah dari waktu ke waktu, sedangkan gender dapat berubah dari waktu ke waktu. Jenis kelamin berlaku di mana saja (universal), sedangkan gender berlaku berbeda dari satu tempat dengan tempat lain. Jenis kelamin tidak dapat dipertukarkan, sedangkan gender dapat dipertukarkan. Dalam ilmu-ilmu sosial, istilah gender kemudian mengacu kepada perbedaanperbedaan antara laki-laki dan perempuan yang merupakan hasil konstruksi sosial dan kultural. Secara khusus, gender adalah pembagian peran, kedudukan, hak dan kewajiban antara laki-laki dan perempuan yang ditetapkan oleh masyarakat berdasarkan sifat perempuan dan laki-laki yang dianggap pantas menurut norma-norma, adat-istiadat, kepercayaan atau kebiasaan masyarakat. ${ }^{5}$

Fakih mengemukakan, gender adalah suatu sifat yang melekat pada kaum lakilaki maupun perempuan yang dikonstruksi secara sosial maunun kultural. ${ }^{6}$ Misalnya, perempuan dikenal lemah lembut, sementara laki-laki dianggap pemberani. Walaupun

${ }^{4}$ Julia Cleves Mosse, Gender dan Pembangunan (Yogyakarta: Pustaka Pelajar, 1996), h. 56; Ann. Oakley. Gender and Society. Bringhamton (New York: Yale University Press, 1972), h. 78; Mansour Fakih, Analisis Gender dan Transformasi Sosial (Yogyakarta: Pustaka Pelajar, 1999), h. 7.

${ }^{5}$ Rianingsih Djohani, Dimensi Gender dalam Pengembangan Program Secara Partisipasif (Bandung: Studio Driya Media, 1996), h. 7.

${ }^{6}$ Ibid. 
pada kenyataannya ciri atau sifat lemah lembut dimiliki laki-laki dan ada pula sifat pemberani dimiliki oleh perempuan. Laki-laki dianggap sebagai makhluk yang tegas dan rasional. Sedangkan perempuan sering dianggap sebagai makhluk yang ragu-ragu dan emosional. Sekali lagi, pada kenyataannya mungkin saja terjadi hal yang sebaliknya.

Gender memiliki perbedaan-perbedaan bentuk antara satu masyarakat dengan masyarakat lain karena norma-norma, adat istiadat, kepercayaan, dan kebiasaan masyarakat yang berbeda-beda. Hal ini dapat diartikan bahwa konsep gender dapat dipandang sebagai konsep yang berbeda berdasarkan budaya masyarakat tertentu dan mungkin berdasarkan pemahaman agama yang membentuk budaya masyarakat tersebut. Gender juga berubah dari waktu ke waktu karena adanya perkembangan yang memengaruhi nilai-nilai dan normanorma dalam budaya masyarakat tersebut. Maka mungkin ditemukan bahwa konsep gender pada suatu masyarakat pada masa ini akan berbeda dengan konsep gender pada masyarakat itu sendiri pada masa sebelumnya atau berbeda dengan konsepnya pada masa yang akan datang. ${ }^{7}$

Di dalam masyarakat terjadi pemahaman yang keliru, di mana gender sering dianggap sebagai kodrat, dan sering dicampuradukkan dengan kodrat perempuan (haid, hamil, melahirkan dan menyusui), misalnya mengasuh anak, mengurus rumah tangga, membersihkan rumah dan memasak (urusan domestik) dianggap sebagai kodrat wanita. Kenyataannya mengasuh anak dan mengurus rumah tangga bisa juga dilakukan oleh laki-laki karena tugas ini bisa digantikan dan tidak bersifat universal sebagai apa yang disebut kodrat. Dengan demikian, mengasuh anak dan merawat rumah tangga adalah masalah gender. Jadi, sesungguhnya perbedaan jenis kelamin tidak berarti juga perbedaan peran gender.

Perbedaan gender selanjutnya melahirkan peran gender yang berbeda pula. Peran gender yang berbeda ini pula yang melahirkan ketimpangan gender atau sering disebut sebagai ketidakadilan dan kesetaraan gender. Ketimpangan gender terjadi bila ada salah satu pihak (laki-laki atau perempuan), dirugikan. Jadi, ketimpangan gender adalah keadaan di mana salah satu pihak mengalami ketertindasan, sementara pihak lain dalam posisi yang lebih baik/diuntungkan. Ketimpangan atau ketidakadilan gender bisa terjadi pada laki-laki dan perempuan. Namun realitanya seringkali perempuan menjadi korban.

\section{Peran Gender}

Dari perbedaan jenis kelamin dan gender yang dijelaskan di atas kemudian muncul dengan apa yang dikenal sebagai "peran kodrati" dan "peran gender". Peran ialah hak-hak dan kewajiban-kewajiban yang harus dijalankan seseorang karena status/kedudukannya. ${ }^{8}$

${ }^{7}$ Ibid.

${ }^{8}$ Ibid. 
Peran kodrati adalah peran yang sifatnya sebagai kodrat yang berkaitan dengan jenis kelamin. Contoh peran kodrati bagi jenis kelamin perempuan antara lain haid, memiliki indung telur, hamil, melahirkan dan menyusui, sedangkan peran kodrati bagi jenis kelamin laki-laki lain menghasilkan sprema dan membuahi. Peran ini tidak dapat dipertukarkan sampai kapan pun dan di mana pun, karena ia merupakan ciptaan Tuhan. Peran gender adalah peran yang muncul karena bentukan budaya dan sosial suatu masyarakat pada suatu waktu tertentu. Peran gender ini buatan manusia. Kondisinya bisa dipertukarkan tanpa memandang jenis kelamin. Peran gender mungkin berubah dari waktu ke waktu dan berbeda dari satu tempat dengan tempat lain.

Peran gender juga dapat diartikan sebagai seperangkat harapan tentang perilaku apa yang pantas dilakukan seseorang dalam masyarakat sesuai dengan identitas gendernya. ${ }^{9}$ Peran gender lahir karena adanya perbedaan gender. Selama peran gender dianggap tidak menimbulkan ketidakadilan, maka ia tidak pernah digugat. Secara biologis (kodrat) kaum perempuan bisa hamil karena konsekwensi dari organ reproduksi yang dimilikinya, kemudian melahirkan, dan menyusui sehingga pada gilirannya ia mempunyai peran gender merawat, mengasuh dan mendidik anak. Dalam hal ini, sesungguhnya tidak menjadi masalah dan tidak perlu digugat. Namun yang menjadi masalah adalah struktur yang menciptakan ketidakadilan sebagai hasil bentukan perbedaan gender dan peran gender tadi. Sesungguhnya, peran gender terkait dengan identitas dan karakteristik yang diasumsikan masyarakatl sosial/kultural kepada laki-laki dan perempuan. Identitas dan karakteristik ini terkait dengan hubungan gender yang pada akhirnya memola peran gender itu sendiri.

Hubungan gender ialah suatu konsep dan realisasi sosial yang berbeda di mana pembagian kerja antara pria dan wanita tidak didasarkan pada pemahaman yang normatif dan kategori biologis, melainkan pada kualitas, dan skill dan yang didasari oleh konvensi sosial. Seyogyanya peran gender tidak berdasarkan pada pandangan normatif dan bias gender melainkan pada kesadaran terhadap kesetaraan hubungan antara laki- laki dan perempuan.

Peran gender yang tercipta dari hubungan gender dapat terjadi dalam berbagai aspek/ bidang kehidupan dan di dalam berbagai lingkungan. Peran gender yang tidak adil juga dapat tercipta dari hubungan gender yang tidak seimbang, baik dalam keluarga, sekolah ataupun masyarakat. Sebagaimana yang diungkapkan Djohani bahwa ketimpangan gender dapat terjadi di mana saja dan berbagai bidang. Ketimpangan gender dapat terjadi dalam lingkungan keluarga, sosial kemasyarakatan, sekolah dan tempat pendidikan. ${ }^{10}$ Ketidakadilan ini juga sebenarnya dimulai sejak anak-anak. Mereka telah menerima didikan tentang nilai-nilai yang berbeda tentang jenis kelamin dan keharusan yang dimiliki atau dilakukan

\footnotetext{
${ }^{9}$ Martin dan Icek Ajzen Fishbein, Belief Attitude, Intention and Behavior: an Introduction to Theory and Research (Massachusetts: Addison Wesley Publishing Company, 1975).

${ }^{10}$ Muhammad Hidayat Rahz (ed.), Perempuan yang Menuntun (Bandung: Ashoka Indonesia, 2000), h. 45.
} 
oleh masing-masing pemilik jenis kelamin tersebut. Nilai-nilai ini kemudian berkembang menjadi hubungan yang tidak seimbang, di mana perempuan tidak menjadi mitra sejajar laki-laki. Akibatnya, ketidak serasian akan terjadi di dalam kehidupan bersama laki-laki dan perempuan, baik dalam lingkup keluarga, sekolah, maupun masyarakat.

Umar mencatat bahwa pemahaman agama yang keliru juga sering dianggap sebagai satu faktor penting yang menyumbangkan hubungan gender yang merugikan perempuan. Dalil-dalil agama sering dijadikan dalih untuk menolak kesetaraan gender. Bahkan dalildalil agama yang pula yang dijadikan referensi untuk melanggengkan hubungan gender sedemikian rupa. Interpretasi dan pemahaman terhadap agama yang demikian telah tertanam sehingga menimbulkan kesan seolah-olah perempuan memang tidak pantas setara dengan laki-laki dan menjadi mitra laki-laki. ${ }^{11}$ Dalam al-Qur'an, hubungan lakilaki dan perempuan, dan suami dan istri sebagai hubungan saling menyempurnakan yang tidak dapat terpenuhi kecuali atas dasar kemitraan. Tidak ada yang membedakan keduanya di hadapan Allah kecuali karena ketakwaannya (Q.S. al-Hujurat/49: 13).

Pada ayat yang menyatakan bahwa derajat laki-laki lebih tinggi yang disinyalir dari penafsiran ayat (Q.S. al-Baqarah/2: 228) dipahami dalam soal kepemimpinan tidak boleh sewenang-wenang, bahkan dalam Tafsîr al-Manar dan Rawâi' al-Bayân dikatakan bahwa posisi hubungan laki-laki dan perempuan adalah sebagaimana hubungan anggota tubuh badan manusia. Hal ini berarti laki-laki menduduki sebagai kepala dan perempuan sebagai anggota badan. Hal ini tidak menunjukkan bagian kepala lebih mulia dari anggota tubuh yang lain. ${ }^{12}$ Menurut al-Sabuni, "derajat" dalam ayat ini (Q.S. al-Baqarah/2: 228) bukan menunjukkan bahwa derajat yang bermakna laki-laki lebih tinggi sebagai makna derajat tasyrif, tetapi yang dimaksud adalah derajat ta'lif (kelebihan dalam beban), yaitu tanggung jawab laki-laki (suami) terhadap keluarganya yang antara lain memberi nafkah keluarga. ${ }^{13}$ Namun Yafie mengungkapkan bahwa dalam Islam, pola hubungan gender (laki-laki dan perempuan) adalah pola kemitraan (al-zawziyah). ${ }^{14}$ Laki-laki adalah mitra sejajar perempuan yang saling melengkapi satu sama lain (ba'dhuhum min ba'din). Dalam al-Qur'an, tegas disebutkan bahwa laki-laki dan perempuan adalah sama dalam unsur kemanusiaan (Q.S. al-Nisâ'/4: 1). Tidak ada perbedaan hak dan derajat (Q.S. al- Hujurat/ 49: 13). Menurut Siti Musdah Mulia, al-Qur'an atau kitab suci lainnya diturunkan dalam suatu lingkup masyarakat yang tidak hampa budaya. Teks-teks al-Qur'an diyakini sarat

${ }^{11}$ Leila Ahmed, Wanita dan Gender dalam Islam, terj. M.S. Nasrulloh (Jakarta: Lentera, 2000), h. 46; Nasaruddin Umar, Argumen Kesetaraan Jender Perspektif al-Qur'an (Jakarta: Paramadina, 1999), h. 8.

${ }^{12}$ Muhammad Râsyid Ridha, Tafsîr al-Manar, Juz V (Beirut: t.p., t.t.), h. 68-69; Muhammad 'Ali al-Sabuni, Rawa'i al-Bayân li Tafsîr Âyât Ahkam min al-Qur'ân (Suriah: Maktabah al-Ghazâlî, 1981M/1391 H.), h. 467; Zaitunah Subhan, Tafsir Kebencian (Studi Bias Gender dalam Tafsir Qur'an) (Yogyakarta: LKiS, 1999), h. 45.

${ }^{13}$ Al-Sabuni, Rawa'i al-Bayân, h. 467.

${ }^{14}$ Muhammad Thalib, Dilema Wanita Karir (Yogyakarta: Wihdah Press, 1999), h. 56. 
dengan nilai-nilai kemanusiaan yang luhur dan adil, hanya saja ketika ajaran yang suci itu turun ke bumi dan berinteraksi dengan beragam budaya manusia, tidak mustahil dalam penafsiran ajaran tersebut timbul distorsi. Pemahaman distortif tersebut itu muncul antara lain karena perbedaan tingkat intelektualitas dan pengaruh latar belakang sosio kultural juga sosio historis manusia yang menafsirkannya. Karena itu, diperlukan pembacaan ulang dan dekonstruksi atau penafsiran yang dinilai bias gender atau bias nilai-nilai patriarki. ${ }^{15}$

\section{Keadilan dan Kesetaraan Gender}

Kata keadilan berasal dari kata, 'adil, yang artinya tidak berat sebelah, tidak memihak; berpegang kepada kebenaran; sepatutnya tidak sewenang-wenang. Sedangkan keadilan diartikan sebagai perbuatan, perlakuan dan sebagainya yang adil. ${ }^{16} \mathrm{Jadi}$, keadilan gender diartikan sebagai suatu keadaan yang cenderung memperlakukan adil antara peran dan posisi perempuan dan laki-laki. Atau keadilan gender juga dikatakan sebagai suatu perlakuan yang sesuai dengan hak dan kewajiban sebagai manusia yang bermartabat dalam keluarga dan masyarakat. Sedangkan kesetaraan berasal dari kata "tara", "setara". Setara artinya sejajar (sama tingginya); sama tingkatnya, kedudukannya dan sebagainya; sepadan, seimbang. ${ }^{17}$ Jadi, kesetaraan adalah suatu kondisi di mana menunjukkan adanya suatu keseimbangan, kesepadanan dan kesejajaran. Dengan demikian, kesetaraan gender dapat diartikan sebagai suatu keadaan yang memperlihatkan keseimbangan, kepadanan dan kesejajaran peran perempuan dan laki-laki. Lebih lanjut, kesetaraan gender juga disebutkan sebagai kesamaan peluang dan kesempatan dalam bidang sosial, politik dan ekonomi antara laki-laki dan perempuan.

Frase 'keadilan dan kesetaran gender' merujuk kepada suatu kondisi yang memperlakukan perempuan dan laki-laki dari segi perannya secara adil dan menempatkan keduanya; perempuan dan laki-laki dalam posisi yang sejajar, seimbang dan sepadan. Dengan kata lain keadilan dan kesetaraan gender adalah terdapatnya suatu kondisi yang adil (equity) dan setara (equality) dalam hak, kesempatan dan hubungan kerjasama antara perempuan dan laki-laki. Hakikat keadilan dan kesetaraan gender adalah relasi sosial antara lakilaki dan perempuan yang harmonis. Hakikat ini antara lain ditunjukkan oleh adanya sikap saling mendukung, saling menghargai dan saling melengkapi antara perempuan dan laki-laki dalam keluarga dan masyarakat.

Suatu keadaan atau kondisi yang tidak melambangkan keadilan dan kesetaraan sebagaimana yang diungkapkan di atas disebut sebagai "ketidakadilan dan ketidak-

\footnotetext{
${ }^{15}$ Badriyah Fayumi, et al., Keadilan dan Kesetaraan Gender Perspektif Islam (Jakarta: Tim Pemberdayaan Perempuan Bidang Agama, 2001), h. xviii -xix.

${ }^{16}$ Departemen Pendidikan dan Kebudayaan, Kamus Besar Bahasa Indonesia (Jakarta: Balai Pustaka, 1995), h. 7.

${ }^{17}$ Ibid., h. 1010.
} 
setaraan gender". Ketidakadilan dan kesetaraan gender mungkin terjadi pada perempuan dan mungkin pada laki-laki. Namun kenyataan menunjukkan bahwa ketidakadilan dan ketidaksetaraan gender sering terjadi pada perempuan. Ketidakadilan dan ketidaksetaraan gender ini termanisfestasikan dalam berbagai bentuk, yaitu marginalisasi, stereotipe, kekerasan (violence), peran ganda (double burden) dan subordinasi. ${ }^{18}$ Makna kelima konsep tersebut akan dibahas di bawah ini.

\section{Marginalisasi}

Marginalisasi adalah suatu proses pemiskinan terhadap perempuan yang timbul sebagai akibat dari kebijakan pemerintah, keyakinan, tafsiran agama, tradisi, budaya dan asumsi ilmu pengetahuan. Marjinalisasi dapat diartikan juga sebagai suatu proses peminggiran seorang atau sekelompok orang sehingga tidak/kurang mempunyai akses dan kontrol atas sumber daya maupun pengambilan keputusan. Proses peminggiran dan pemiskinan tersebut antara lain pekerjaan yang digolongkan lebih tidak bernilai dari yang lain hanya karena pembedaan jenis kelamin. Contoh, pekerjaan perempuan dinilai lebih rendah dari pekerjaan laki-laki atau perempuan dianggap tidak sekuat laki-laki sehingga pekerjaan perempuan dianggap lebih sedikit produktivitasnya sehingga gaji yang diberikan kepadanya juga lebih kecil dari laki-laki. Dari contoh ini, maka terjadi proses peminggiran dan pemiskinan terhadap perempuan. Marginalisasi ini juga merambah kepada bidang sosial dan ekonomi yang pada akhirnya meminggirkan, dalam hal ini, perempuan untuk mendapat akses kepada bidang-bidang ekonomi dan sosial itu. Contoh lain sering didengar seorang istri atau seorang perempuan tidak bisa meminjam uang ke bank tanpa izin suaminya atau ayahnya, sekalipun peluang meminjam uang ke bank itu memungkinkan.

Pada kehidupan sehari-hari di berbagai bidang, juga masih ditemukan fakta bahwa perempuan harus mengalah kepada laki-laki (suami kepada istrinya) tanpa ada tawar menawar lagi. Perempuan sering dikonotasikan sebagai makhluk yang lebih pantas di belakang layar dan tidak layak tampil ke depan. Sebaliknya, laki-laki sering diutamakan dan dianggap paling layak tampil ke depan, baik dalam musyawarah ataupun pada peristiwa yang lebih besar lagi.

\section{Stereotipe}

Stereotipe adalah pelabelan yang bersifat negatif atau penandaan terhadap seseorang atau sekelompok orang yang kebenarannya belum dapat dibuktikan secara empiris. Stereotipe sering tidak menunjukkan data yang sebenarnya. Paling tidak, stereotipe tidak berlaku sebagai akibat dari sebab kondisi yang dilabelkan itu. Stereotipe terkesan berlaku selamanya dan tidak bisa dirubah. Karena itu, stereotipe tidak bisa menjadi pegangan

\footnotetext{
${ }^{18}$ Fakih, Analisis Gender, h. 8.
} 
untuk menilai sifat, watak, label pada seseorang atau sekelompok orang. Stereotipe kepada perempuan dan laki-laki sering diungkapkan bahwa perempuan pengecut dan laki-laki pemberani. Perempuan cengeng dan laki-laki bersifat tegas. Perempuan tukang masak, dan laki-laki tidak pantas memasak. Contoh-contoh lain, perempuan itu dianggap sebagai makhluk penggoda, maka laki-laki harus hati-hati terhadap perempuan karena godaannya lebih dahsyat dari setan. Akibatnya, bila terjadi kasus pelecehan atau perkosaan masyarakat cenderug menyalahkan perempuan, padahal mereka adalah korbannya.

Stereotipe yang dilabelkan kepada perempuan dan laki-laki cenderung merugikan salah satu pihak atau mengecewakan harapan sekelompok orang terhadap pihak tersebut. Misalnya dipercayai bahwa setiap laki-laki adalah pemberani, namun kenyataannya ditemukan banyak juga laki-laki yang pengecut. Sering diduga bahwa perempuan tidak bisa bersifat tegas, lalu masyarakat tidak melibatkan perempuan sebagai pengambil keputusan, akhirnya perempuan dirugikan. Masyarakat juga sering merasa kecewa juga melihat ternyata banyak laki-laki yang tidak bisa tegas. Faktanya bahwa memang stereotipe sering merugikan perempuan. Stereotipe yang dilabelkan kepada perempuan mengakibatkan perempuan berada pada tempat nomor dua, sehingga akses, peran, kontrol dan manfaat perempuan terhadap suatu aktivitas atau program sering terlupakan bahkan diabaikan.

\section{Kekerasan}

Kekerasan atau disebut juga violence dapat diartikan suatu tindakan yang dilakukan oleh satu orang atau lebih yang dapat membahayakan satu orang lain atau lebih secara fisik ataupun non fisik. Definisi ini sebagaimana yang diungkapkan oleh Wemer et al., “...the reat, attempt or use of physical force byone or more persons that result in physical or non physical harm to one or more other person..."19 Dari definisi di atas dapat disimpulkan bahwa secara umum kekerasan memiliki dua macam bentuk, yakni kekerasan yang membahayakan secara fisik dan kekerasan yang membahayakan secara non fisik. Nonfisik sendiri memiliki arti yang lebih luas lagi yaitu meliputi hal-hal yang abstrak seperti psikologis, emosional atau aspek lain dari kehidupan seseorang.

Kekerasan bisa terjadi di mana saja, di keramaian atau di tempat sunyi bahkan sekalipun di tempat yang dianggap sebagai tempat bernaung dan berlindung yaitu rumah dalam keluarga. Istilah untuk mewakili kekerasan yang terjadi di rumah tangga inilah yang kemudian menjadi isu menarik bagian dari kajian gender, yaitu kekerasan dalam rumah tangga. Kekerasan adalah serangan terhadap fisik maupun integritas mental seseorang. Kekerasan dapat dikategorikan dalam ketimpangan gender seperti pemerkosaan.

Merujuk kepada definisi yang telah diberikan di atas, maka kekerasan dalam rumah

${ }^{19}$ N.A. M. Ar. Zahn Wemer \& R.S. Sagi, Violence Pattern, Causes, Public Policy (New York: Harcourt Brace Jovanovich, t.t.), h. 13. 
tangga dapat diartikan sebagai satu tindakan yang dikenakan kepada setiap anggota keluarga yang membuat korban mengalami kerugian fisik, psikis, sosial, dan emosional. Anggota keluarga yang menjadi korban kekerasan dalam rumah tangga mungkin suami, istri, anak, ayah, ibu atau adik yang menjadi anggota sebuah keluarga.

Kekerasan dalam rumah tangga temasuk juga kekerasan yang menimpa siapa saja yang bukan anggota keluarga, tetapi juga mereka tinggal di dalam lingkungan suatu rumah misalnya pembantu rumah tangga. ${ }^{20}$ Umumnya kekerasan dalam rumah tangga terjadi karena adanya salah satu pihak merasa superior dibanding yang lain, karena itu sering sekali kekerasan dalam rumah tangga terjadi jauh lebih banyak kasus kekerasan oleh suami kepada istri daripada sebaliknya, ${ }^{21}$ karena laki-laki sering merasa superior dari perempuan.

Ciri-ciri kekerasan dalam rumah tangga antara lain tertutupnya hak-hak korban untuk hidup sejahtera, terganggunya kenyamanan di dalam rumah sendiri, atau ketentraman hidup korban di tengah keluarganya sendiri. Seorang korban kekerasan dalam rumah tangga bahkan merasa tidak aman tinggal di tempat berlindungnya, tidak mempercayai anggota keluarga yang lain dan merasakan tekanan hidup.

Pada dasarnya, kekerasan dalam rumah tangga terjadi adalah diakibatkan dari tidak adanya kesetaraan atau keadilan gender. Fakih mengatakan bahwa ketidakadilan gender berwujud dalam berbagai bentuk, yakni marginalisasi atau proses pemiskinan ekonomi, kekerasan (violence), stereotipe, subordinasi bahwa perempuan itu makhluk kedua yang tidak berhak mengambil keputusan dalam hal-hal publik politik ataupun beban ganda dalam bekerja tanpa ada penilaian/penghargaan bagi perempuan tersebut. ${ }^{22}$

\section{Beban Ganda}

Peran perempuan dalam keluarga dan masyarakat sangat beragam dan berganda telah disadari, terlebih-lebih fungsi dan perempuan dalam keluarga yang tidak dapat digantikan dilakukan oleh laki-laki (mengandung, melahirkan, dan menyusui) dan yang lebih dominan dari laki-laki (memelihara anak, mengelola urusan rumah tangga, memberi perhatian, dan kasih sayang menanamkan nilai-nilai moral/agama). Fungsi yang disebutkan pertama tadi adalah fungsi kodrati (haid, hamil, melahirkan, dan menyusui) yang memang tidak dapat digantikan oleh laki-laki. Sedangkan yang disebutkan kedua

${ }^{20}$ R.S. Kolibonso, "Kekerasan dalam Rumah Tangga sebagai Pelanggaran Hak Asasi Manusia," dalam A.S. Luhalima (ed.)., Pemahaman terhadap Bentuk-bentuk Kekerasan terhadap Perempuan dan Alternatif Pemecahannya (Jakarta: Kelompok Kerja "Convention Watch," Pusat Kajian Wanita Fewleral, 2000), h. 109.

${ }^{21}$ Farha Ciciek, Ikhtiar Mengatasi Kekerasan dalam Rumah Tangga (Jakarta: LKAJ, PSP, The Asia Foundation, 1999), h. 22.

${ }^{22}$ Fakih, Analisis Gender, h. 26-31. 
sebenarnya adalah fungsi gender (mengasuh, memelihara dan memberikan kasih sayang) yang dihasilkan dari bentukan budaya yang cukup panjang.

Kedua fungsi tersebut berada pada ranah domestik. Pada ranah domestik itu sendiri perempuan telah memiliki beban ganda. Peran domestik mengurus rumah tangga mulai masalah makanan (menyiapkan menu, berbelanja, menyiapkan makanan, dan menghidangkan), kebersihan (menyapu, mengepel, dan mencuci piring) sampai masalah pakaian (menyuci, menyetrika dan merapikan) semua dilakukan perempuan. Tampak jelas peran domestik telah membebani perempuan dengan beban kerja yang sangat banyak. Lebihlebih lagi, anggapan bahwa perempuan tidak cocok menjadi kepala rumah tangga, berakibat bahwa sejumlah pekerjaan domestik rumah tangga menjadi tugas dan tanggungjawab dan kewajiban perempuan.

Dalam kondisi perempuan yang hidup pada suami yang memiliki perekonomian yang lemah, maka perempuan sering kali membantu suami mencari tambahan pendapatan. Karena keadaan memaksa, perempuan harus bekerja mencari nafkah. Biasanya keadaan yang terjadi perempuan boleh mencari nafkah asal tidak meninggalkan semua pekerjaan yang telah membebani mereka. Perempuan akan menerima keadaan itu dan karena lilitan ekonomi membuat dia tidak bisa mengurus rumah tangga dengan baik. Akhirnya, perempuan tidak hanya memiliki beban ganda di ruang domestik, tetapi juga beban di ruang publik.

Beban ganda perempuan ini tidak hanya memberikan beban kerja yang berat, tapi juga beban kerja yang panjang. Hal ini terutama dialami oleh perempuan yang bekerja di luar rumah atau mereka yang bekerja sebagai pembantu rumah tangga. Perempuan dituntut untuk menyelesaikan tugas-tugas rumah tangga yang dalam masyarakat selalu dipersepsikan sebagai kewajiban perempuan. Pada ruang publik, perempuan juga dituntut untuk menunjukkan prestasi di tempat kerjanya.

Beban ganda ini berakibat dari konsep budaya yang cukup panjang dan lama ditambah lagi oleh pemahaman ajaran agama yang tidak tepat. Anggapan bahwa kerja rumah tangga, membersihkan, memasak, mengurus dan mendidik anak adalah sebagai tugas perempuan semata didukung oleh pemahaman budaya tertentu yang menganggap bahwa apabila laki-laki melakukan pekerjaan tersebut adalah hal yang memalukan. Laki-laki dianggap tidak pantas melakukan pekerjaan yang sudah menjadi lambang pekerjaan perempuan. Membantu pekerjaan istri juga dianggap sebagai hal yang memalukan karena akan menimbulkan cemoohan masyarakat bahwa laki-laki (suami) tersebut terkesan berada di bawah perintah istrinya.

\section{Subordinasi}

Subordinasi atau penempatan adalah suatu keyakinan dan sikap bahwa salah satu jenis kelamin dianggap lebih tinggi atau penting atau utama dibanding dengan jenis kelamin lainnya. Contoh subordinasi yaitu menganggap dan menempatkan posisi laki-laki pada 
posisi lebih penting daripada posisi perempuan. Perempuan dianggap tidak penting sehingga ia sering tidak mendapat akses, peran, kontrol dan manfaat dari suatu sumber daya dan pengambilan keputusan. Hal ini disebabkan oleh anggapan bahwa perempuan itu irrasional dan emosional sehingga tidak bisa tampil sebagai seorang yang penting. Perempuan tidak cerdas sebagaimana layaknya laki-laki. Maka masyarakat sering kesulitan memperjuangkan perempuan yang sebenarnya layak menjadi pemimpin karena masih kuatnya anggapan bahwa pemimpin harus seorang laki-laki. Kalaupun ada seorang pemimpin perempuan, sering didengar komentar-komentar yang menyalahkan keadaan yang ada sebagai akibat mengangkat perempuan sebagai pemimpin. Akhirnya pandangan ini sering membawa kepada dampak yang lain pada bidang-bidang yang lainnya seperti laki-laki harus memiliki pendidikan, sedangkan tidak mengapa bila perempuan tidak berpendidikan; atau lakilaki harus memiliki pendidikan lebih tinggi dari perempuan. "Perempuan tidak perlu sekolah tinggi-tinggi" karena pada akhirnya akan kembali ke dapur juga."

Munculnya ketidakadilan dan ketidaksetaraan gender tampaknya sebagai suatu lingkaran yang saling berhubungan sebagai sebab akibat. Ketika telah terjadi satu indikator ketidakadilan gender, maka jelas memungkinkan lahirnya ketidakadilan yang lain. Misalnya stereotipe bagi perempuan sebagai orang yang bersifat cengeng, pemalu dan tidak bias bersifat tegas (stereotipe) menyebabkan perempuan itu tidak dapat mengakses posisi sebagai pengambil keputusan atau sebagai pemimpin. Karena hal ini dianggap tidak pantas (subordinasi). Karena perempuan tidak pantas tampil sebagai pemimpin, maka ia hanya sebagai pendamping yang membantu suami, kalau mungkin dalam segala hal (beban ganda). Karena laki-laki adalah pemimpin bagi perempuan, maka ia boleh melakukan apa saia terhadap perempuan (kekerasan), apalagi yang memberi nafkah, pakaian perempuan tersebut adalah laki-laki atau suaminya yang menentukan tindakan apa saja yang akan dilakukan istri (marginalisasi). Tampaknya, kctidakadilan dan ketidaksetaraan gender hanya bisa dieliminasi bila upaya-upaya mengeliminir kelima indikator tersebut sekaligus dapat dilakukan. Bila upaya ini tercapai, maka keadilan dan kesetaraan gender dapat pula tercapai.

\section{Perspektif Islam tentang Gender}

Ajaran agama sebenarnya mengajarkan kesetaraaan. Manusia diciptakan dari jenis berbangsa-bagsa dnn bersuku-suku adalah sebuah prinsip yang menyatakan bahwa setiap manusia itu berbeda, tapi mereka adalah setara kedudukannya di hadapan sang Pencipta. Yang membedakan adalah prestasi hidup dan kehidupan dalam kebaikan (takwanya). Tidak ada manusia yang lebih utama dan lebih penting dari manusia yang lain. Demikian juga tidak ada jenis kelamin yang lebih penting dari jenis kelamin yang lain.

Agama juga mengajarkan untuk tidak memberi label (laqab) yang tidak ada dasar berpijaknya sekaligus yang tidak disukai oleh orang yang diberi label (Q.S. al- Hujurat/ 49:11). Apalagi pelabelan yang tidak memiliki dasar tersebut menjadi suatu prasangka 
terhadap orang lain (Q.S. al- Hujurât/49: 12), sehingga prasangka tersebut membentuk cara berpikir yang salah terhadap orang lain tersebut. Dalam masalah peran ganda, agama juga menghendaki keadilan. Agama juga mengajarkan untuk tidak berlaku zalim. Membebani orang lain secara berlebihan adalah termasuk perbuatan yang tidak adil dan zalim. Agama juga tidak menghendaki kekerasan. Dalam kaitannya dengan kekerasan dalam rumah tangga, agama tidak mentolerir jenis kekerasan apapun, baik kekerasan fisik, psikis, ekonomi dan seksual. Agama mengajarkan bagaimana manusia menyayangi keluarganya, termasuk orangtua, pasangan hidup, anak-anak dan siapa saja yang ada di sekitar lingkungan. Namun ajaran agama akan terlaksana bila dipahami secara benar dan diamalkan dengan kepatuhan.

Agama Islam, misalnya, mengajarkan kepada suami untuk berlaku baik kepada istrinya. Suami harus mendidik istrinya. "perempuan-perempuan yang kamu khawatirkan nusyuznya (istriyang membangkang kepada suami dalam kebaikan) maka nasehatilah mereka dan pisahkanlah mereka di tempat tidur mereka, dan pukullah mereka. Kemudian jika mereka mentaatimu maka janganlah kamu mencari jalan untuk menyusahkannya. Sesungguhnya Allah Maha Tinggi lagi Maha Besar" (Q.S. al-Nisâ'/4: 34). Pada ayat yang lain, "dan jika seorang wanita khawatir akan nusyuz atau sikap tidak acuh dari suaminya, maka tidak mengapa bagi keduanya mengadakan perdamaian yang sebenar-benamya..." (Q.S. al-Nisâ'/ 4: 128). Ayat ini terkesan memihak laki-laki. Ayat ini juga sering dijadikan dasar bagi ulama ortodoks untuk melegalisasi supremasi laki-laki. Zamakhsyari memberikan konteks pewahyuan bahwa ayat ini menjelaskan bahwa seorang pemimpin Ansar, Sa'ad bin Rabi' menampar istrinya, Habibah binti Zaid, karena tidak taat padanya. Karena merasa diperlakukan tidak baik, maka Habibah mengeluhkan kepada ayahnya, dan ayahnya menyampaikan masalah ini kepada Rausulullah. Lalu Rasulullah menganjurkan Habibah membalasnya. ${ }^{23}$

Namun ketika budaya kesetaraan perempuan dan laki-laki masih sangat asing, anjuran Rasulullah menuai protes dari masyarakat. Lalu turun Q.S. al-Nisâ'/4: 34. Dalam surat ini dijelaskan kedudukan istri yang harus taat kepada suami dalam kebaikan, namun bila istri membangkang terdapat langkah-langkah yang harus ditempuh oleh suami. Bukan ajaran memukul istri yang harus diterapkan langsung. Langkah pertama istri dinasehati. Kedua, bila tidak juga berubah baik, maka istri dipisahkan ranjangnya atau diabaikan di tempat tidur, bila tidak juga berubah menjadi baik, maka suami boleh memukul dengan tidak menyakiti. Memukul merupakan jalan keluar terakhir untuk menyadarkan istri yang berbuat salah. Jadi memukul hanya diperbolehkan pada situasi dan kondisi tertentu dengan aturan tenentu pula.

Seorang suami juga dituntut bergaul dengan baik dengan istri baik dalam maupun tingkah laku (Q.S. al-Nisâ'/4: 19). Rasulullah juga mengatakan bahwa "sebaik-baik kalian (laki-laki) adalah orang yang paling baik terhadap istrinya." "Sebaik-baik kamu adalah

${ }^{23} Z a m a k h s y a r i$, Tafsîr al-Kasyaf (Beirut: Dâr al-Kutub al-'Ilmiyyah, t.t.), h. 254; Wahbah al-Zuhaili, Nizham al-Islâm (Beirut: Dâr Qutaibah, 1993), h. 67. 
yang paling terhadap keluarganya dan aku adalah orangyang paling baik terhadap keluargaku. Tidak menghormati perempuan kecuali orangyang mukmin dan orangyang menghina perempuan adalah orang yang tercela." Rasulullah sangat memperhatikan sopan santun dalam pergaulan dengan istri dan keluarga, mulai tata cara berkomunikasi sampai dengan tata cara hubungan seksual. Bila memanggil istrinya ia mcmanggil dengan panggilan yang disukai istri-istrinya. Dalam konsep Islam, hubungan seks adalah suatu bagian mu'asyarah yang berprinsip pada mawaddah wa rahmah. Hubungan seksual harus mengikuti prinsip-pinsip mu'asyarah bi al-ma'rûf (hubungan yang baik yang disukai oleh kedua belah pihak. Istri-istri kamu adalah adalah pakaian bagimu, dan kamu adalah pakaian bagi mereka.

Selain hubungan seksual Islam juga mengajarkan kepada suami untuk memenuhi kebutuhan fisik keluarga, menyediakan rumah, pakaian, dan makanan. Sebagai balasannya, istri harus menjaga rumah suaminya, mengurusnya, memasak, mencuci, dan membersihkan. "dan kewajiban ayah untuk memberi nafkah dan makan kepada para ibu dengan cara yang ma'ruf..." (Q.S. al-Baqarah/2: 233). Dari Hakîm bin Mu'awiyah al-Qusyairî, dari ayahnya berkata, ya Rasulullah, apakah hak istri dari suaminya?" Nabi menjawab "memberi makan bila kamu makan, memberi pakaian bila kamu berpakaian. Tidak boleh memukul wajah, menjelekkan kecuali di dalam rumah." Dari Jâbir dari Nabi Muhammad SAW., beliau bersabda tentang penyebutan istri-istri, wajib atas kamu memberi nafkah kepada mereka dan pakaian sacara ma'ruf (H.R. Muslim). Dari Ibn 'Umar bahwa Rasullulah SAW. juga pernah bersabda "cukuplah bagi seseorang sebagai pelaku dosa bila dia menyia-nyiakan (tidak memberikan) nafkah kepada orang yang wajib diberinya makan" (H.R. al-Nasâ’i). Bahkan ketika seorang suami tidak mampu memberi nafkah kepada istrinya, ia bisa diancam untuk dipisahkan dari istrinya. Dari Sa'id bin al-Musayyab tentang suami yang tidak mampu menafkahi istrinya "keduanya harus dipisahkan" (H.R. Sa'id bin Manshûr). Seorang istri mempunyai hak menuntut nafkah kepada suaminya. Islam melarang keras suami menelantarkan istri dan keluarganya. Jika menelantarkan saja tidak boleh, tentu lebih tidak boleh memaksa istri bekerja demi kebutuhan keluarga, dan memaksa istri memberi uang kepada suami.

Meskipun seorang suami berkewajiban memberi nafkah kepada istrinya, dan seorang istri harus mengurusi kebutuhan suaminya, namun suami tidak boleh melarang istrinya jika ingin bekerja di luar rumah. Suami hanya boleh melarang istrinya bekerja jika hal itu dapat mendatangkan mudarat (kesulitan) bagi istri dan keluarganya. Hal ini dapat didasarkan pada penghargaan al-Qur'an terhadap pekerjaan anak perempuan Nabi Su'aib as. ketika menjadi penggembala kambing (Q.S. al-Naml/27: 20). Beberapa sahabat perempuan pada masa Nabi Muhammad SAW. juga melakukan berbagai pekerjaan baik dalam bidang ekonomi, sosial, dan agama. Dalam fikih juga tidak ada larangan bagi istri untuk bekerja. Pada dasarnya, bila ajaran agama dipahami secara benar dan ditaati dengan patuh upaya mengeliminir ketidakadilan dan ketidaksetaraan gender akan lebih mudah, bahkan mungkin tidak akan terjadi. Dengan demikian, tercapainya kesetaraan dan keadilan gender adalah 
tercapainya suatu kondisi yang terhindar dari lima hal di atas, yaitu tidak terjadi marginalisasi, subordinasi, stereotipe, kekerasan, dan peran ganda.

\section{Metode Penelitian}

Penelitian ini dilaksanakan di pinggiran Kota Medan yang akan mengambil lokasi di lima kecamatan: Medan Tembung, Kecamatan Medan Amplas, Medan Tuntungan, Medan Sunggal dan Medan Marelan. Medan Tembung memiliki 7 (tujuh) kelurahan yaitu Tembung, Bandar Selamat, Bantan Timur, Bantan, Sidorejo, Sidorejo Hilir, dan Indra Kasih. Medan Amplas memiliki tujuh (tujuh) kelurahan yaitu Amplas, Siderejo II, Sidorejo III, Harjosari I, Harjosari II, Timbang Deli dan Bangun Mulia. Medan Tuntungan memiliki 11 kelurahan yaitu Ladang Bambu, Sido Mulyo, Lau Cili, Namo Gajah, Kemenangan Tani, Simalingkar B, Simpang Selayang, Tanjung Selamat, PB Selayang II, Asam Kumbang, Tanjung Sari. Medan Sunggal memiliki 6 (enam) kelurahan yaitu Tanjung Rejo, Babura, Simpang Tanjung, Sei Sikambing B, Sunggal dan Kampung Lalang. Medan Marelan memiliki 5 (lima) kelurahan yaitu Labuhan Deli, Rengas Pulau, Terjun, Tanah Enam Ratus, dan Paya Pasir.

Populasi penelitian ini adalah seluruh Mubaligh dan Mubalighah yang ada di lima kecamatan pinggiran kota Medan tersebut. Mubaligh dan Mubalighah yang dijadikan responden adalah Mubaligh dan Mubalighah yang masih aktif, baik laki-laki maupun perempuan. Berdasarkan data yang tercatat di Ikatan Dai Indonesia (IKADI), jumlah Mubaligh dan Mubalighah yang ada di seluruh lima kecamatan tersebut berjumlah 135 orang. Sampel ditentukan secara purposive sampling. Sampel ini dilakukan untuk memperoleh responden yang diharapkan dapat mewakili jenis kelamin. Akhirnya, sampel yang didapatkan sebesar 45 orang, yang terdiri atas 16 Mubalighah dan 29 Mubaligh.

Data dalam penelitian ini akan dikumpulkan melalui angket yang dianggap sebagai alat pengumpul data yang tepat. Dengan angket ini dapat diketahui tentang keadaan data diri, pengetahuan, persepsi dan pendapat responden sehingga dapat diharapkan dapat diketahui persepsi Mubaligh dan Mubalighah. Angket yang digunakan adalah angket terbuka. Dengan angket model ini, diharapkan dapat menjaring alasan-alasan bagi pilihan jawaban yang telah disediakan. Pertanyaan-pertanyaan dalam setiap item angket disediakan dua jawaban ekstrim yaitu setuju dan tidak setuju. Kemudian pilihan diberi ruang terbuka untuk memberi alasan bagi jawaban yang dipilihnya. Selain menggunakan angket, untuk memperkaya informasi tentang bagaimana persepsi atau pandangan Mubaligh dan Mubalighah, data akan dikumpulkan juga dengan wawancara tidak terstruktur kepada beberapa responden penelitian yang diminta mengisi angket penelitian tersebut. Analisis data yang digunakan adalah analisis kuantitatif dengan teknik presentasi dan korelasi. Data yang dikumpulkan dengan wawancara akan dijabarkan secara deskriptif. 


\section{Hasil dan Pembahasan}

\section{Persepsi Mubaligh dan Mubalighah terhadap Marginalisasi}

Pengumpulan data tentang persepsi terhadap marginalisasi dilihat dari 6 (enam) indikator yaitu izin suami ketika setiap kali keluar rumah, gaji perempuan dibandingkan dengan gaji laki-laki untuk jenis pekerjaan yang sama, akses istri meminjam uang ke bank, posisi laki-laki terhadap perempuan, posisi perempuan terhadap laki-laki, dan pekerjaan istri dalam rumah tangga dibandingkan dengan pekerjaan suami mencari nafkah.

Setelah dilakukan pengumpulan berdasarkan jenis kelamin, maka diperoleh data Mubaligh (laki-laki) yang berpandangan bahwa seorang istri harus minta izin keluar rumah sebanyak 16 orang (55.17\%), sedangkan 10 orang atau sebanyak $44.83 \%$ menyatakan tidak perlu minta izin. Sedangkan Mubalighah (perempuan) menyatakan seorang istri harus minta izin kepada suaminya setiap kali keluar rumah sebesar 6 orang atau $37.5 \%$ dan sebesar 10 orang atau $62.5 \%$ menyatakan tidak perlu minta izin kepada suami bila setiap kali keluar rumah. Dari data ini menunjukkan bahwa Mubaligh laki-laki lebih banyak mengatakan bahwa istri harus minta izin kepada suaminya keluar rumah, karena seorang suami harus tahu ke mana istrinya pergi, sedangkan perempuan lebih banyak menyatakan tidak perlu minta izin setiap kali keluar rumah bila untuk pekerjaan rutinitas karena sangat menyulitkan. Jadi, cukup dengan memberi tahu saja.

Pada tema gaji seorang perempuan layak lebih kecil dari pada gaji seorang laki-laki dalam jenis pekerjaan yang sama, maka terlihat bahwa 5 orang atau sekitar $17.27 \%$ Mubaligh (laki-laki) menyatakan setuju, dan 24 orang (82.76\%) menyatakan tidak setuju, Sedangkan Mubalighah (perempuan) 16 orang atau sejumlah seratus persen menyatakan tidak setuju. Dari sini tampak bahwa Mubaligh laki-laki dan Mubalighah perempuan memiliki persepsi yang sama bahwa tidak ada perbedaan gaji pada laki-laki dan perempuan pada jenis pekerjaan dan frekwensi yang sama.

Berkenaan dengan akses ke bank bahwa seorang istri tidak bisa meminjam uang ke bank tanpa izin suaminya, maka diketahui 20 orang (68.96\%) Mubaligh (laki-laki) menyatakan setuju, sedangkan 9 orang (31.04\%) menyatakan tidak setuju. Sedangkan 12 orang (75\%) Mubalighah (perempuan) menyatakan setuju bahwa seorang perempuan tidak bisa meminjam uang ke bank tanpa izin suaminya, dan 4 orang (25\%) menyatakan tidak setuju. Tampak bahwa ada perbedaan persepsi Mubaligh laki-laki dan perempuan tentang adaya keharusan adanya izin suami ketika pinjam uang ke bank.

Berkaitan dengan posisi laki-laki terhadap perempuan, ditemukan bahwa 5 orang (17.24 \%) Mubaligh menyatakan bahwa laki-laki dalam segala hal harus diutamakan, sedangkan 24 orang ( $82.76 \%$ ) menyatakan tidak setuju bahwa laki-laki dalam segala hal harus lebih diutamakan. Sedangkan seluruh Mubalighah, 16 orang (100\%), menyatakan tidak setuju bahwa laki-laki dalam segala harus diutamakan. Dari data tersebut masih ada 
yang berpendapat bahwa laki-laki dalam segala hal harus diutamakan, sedangkan mayoritas berpendapat laki-laki tidak selalu harus diutamakan.

Sebaliknya, berkenaan dengan posisi perempuan terhadap laki-laki, 10 orang (34.48\%) Mubaligh menyatakan bahwa perempuan harus mengalah kepada laki-laki dan 19 orang (65.52-1\%) menyatakan tidak setuju bahwa perempuan harus mengalah kepada laki-laki. Sementara 16 orang (100\%) Mubalighah menyatakan tidak setuju terhadap pernyataan bahwa perempuan harus mengalah kepada laki-laki.

Pandangan terhadap pekerjaan istri dalam rumah tangga, 2 orang (6.90\%) Mubaligh menyatakan setuju bahwa pekerjaan istri tidaklah utama, karena tidak memuat nilai ekonomi, sedangkan 27 orang (93.10\%) menyatakan tidak setuju bila dikatakan bahwa pekerjaan istri dalam rumah tangga tidak utama, karena tidak mengandung nilai ekonomi. Sementara 1 orang (6.25\%) Mubaligah menyatakan setuju bahwa pekerjaan istri dalam rumah tangga tidaklah utama, karena tidak mengandung nilai ekonomi. Selebihnya, 15 orang (93.75\%) menyatakan tidak setuju bila dikatakan bahwa pekerjaan istri tidak utama karena tidak memuat nilai ekonomi. Data ini menunjukkan bahwa masih ada sebagian kecil dari lakilaki dan perempuan sendiri yang berpendapat bahwa pekerjaan perempuan (istri) tidak utama dan tidak mempuyai nilai ekonomi.

\section{Persepsi Mubaligh dan Mubalighah terhadap Stereotipe}

Persepsi Mubaligh dan Mubalighah terhadap konsep stereotipe dilihat dari 5 (lima) indikator, yaitu sifat perempuan cengeng, sifat laki-laki pemberani, perempuan lebih lemah dari laki-laki, pekerjaan rumah tangga adalah pekerjaan istri saja dan pekerjaan mengasuh dan mendidik anak adalah pekerjaan istri saja. Data menunjukkan bahwa seluruh Mubaligh dan Mubalighah (laki-laki dan perempuan) menyatakan tidak setuju bila dikatakan bahwa semua perempuan bersifat cengeng dan pemalu.

Terhadap pernyataan semua laki-laki bersifat pemberani dan bersifat tegas, 9 orang Mubaligh (31.04\%) menyatakan setuju dan 20 orang (68.96\%) menyatakan tidak setuju. 2 (dua) orang (12.50\%) Mubalighah menyatakan setuju bahwa laki-laki semuanya bersifat tegas dan pemberani, 14 orang (87.50\%) Mubalighah tidak setuju. Dari data itu bahwa mayoritas Mubaligh dan Mubalighah cenderung menolak bahwa semua laki-laki bersifat pemberani dan tegas. Namun masih ada sekitar $31 \%$ menyatakan bahwa semua lakilaki bersifat pemberani dan tegas. Hal ini menunjukkan bahwa telah mulai ada kesadaran bahwa sifat tersebut bukan kodrat melainkan pelabelan yang diberikan oleh masyarakat sebagai sifat yang dapat dipertukarkan.

Berkaitan dengan pernyataan bahwa semua perempuan secara fisik lebih lemah dari wanita, 12 orang (41.38\%) Mubaligh menyatakan setuju, dan 17 orang (58.62\%) menyatakan tidak setuju. Sedangkan Mubalighah yang menyatakan setuju terhadap pernyataan bahwa perempuan secara fisik lebih lemah dari laki-laki sebanyak 6 orang 
(37.5\%), dan tidak setuju sebanyak 10 orang (62.5\%). Hal ini tampak bahwa mayoritas Mubaligh menyatakan bahwa tidak benar secara fisik lebih lemah dari laki-laki.

Seluruh Mubaligh (laki-laki) setuju bahwa pekerjaan rumah tangga bukanlah hanya tanggung jawab istri saja. Sementara 4 orang Mubalighah ((25\%) setuju bahwa pekerjaan rumah tangga adalah pekerjaan yang menjadi tanggung jawab istri saja, dan 12 orang (75\%) tidak setuju kalau pekerjaan rumah tangga dianggap sebagai pekerjaan istri saja. Jadi, justru pada Mubalighah perempuan yang menyatakan bahwa pekerjaan memasak dan mengurus rumah tangga adalah memang tanggung jawab istri saja.

Pada pernyataan pekerjaan mendidik dan mengasuh anak adalah pekerjaan istri saja, 16 orang (55.17\%) Mubaligh setuju, dan 13 orang (14.83\%) tidak setuju dengan pernyataan ini. Sedangkan seluruh Mubalighah tidak setuju bila dikatakan bahwa tanggung jawab mendidik dan mengasuh anak merupakan tanggung jawab istri saja.

\section{Persepsi Mubaligh dan Mubalighah terhadap Kekerasan}

Pada konsep kekerasan, dilihat 5 (lima) indikator yaitu istri boleh dipukul kalau bersalah, suami tetap menjadi pemimpin keluarga sekalipun tidak memberi nafkah, dalam masalah seksual suami harus dilayani kapan pun dia mau, istri memiliki hak cerai, dan istri wajib mematuhi semua kata-kata suaminya.

Setelah dilakukan pengumpulan data, dapat dilihat bahwa seluruh Mubaligh, 29 orang (100\%), dan Mubalighah sebanyak 16 orang tidak setuju terhadap indikator bahwa istri boleh dipukul apabila melakukan kesalahan.

Ditemukan bahwa 13 orang (44.83\%) Mubaligh setuju terhadap pernyataan bahwa apabila suami tidak memberi nafkah istrinya, masih menjadi pemimpin rumah tangga, dan 16 orang (55.17) tidak setuju apabila suami yang tidak memberi nafkah keluarganya masih menjadi pemimpin rumah tangga. Sedangkan 7 orang (43.75\%) Mubalighah menyatakan setuju bila suami yang tidak memberi nafkah istrinya masih menjadi pemimpin rumah tangga, dan 9 orang (S6.25\%) menyatakan tidak setuju. Dari data ini menunjukkan bahwa mayoritas Mubaligh dan Mubalighah menyatakan bahwa laki-laki yang tidak memberi nafkah keluarga tidak layak menjadi kepala keluarga. Namun perbedaannya tidak seberapa jauh dengan pendapat yang mengatakan bahwa laki-laki yang tidak memberi nafkah tetap menjadi kepala keluarga. Hal tersebut menunjukkan bahwa di kalangan Mubaligh dan Mubalighah masih terjadi beragam pemahaman baik dari konsep nas al-Qur'an dan budaya yang dianutnya.

Dalam masalah seksual, suami harus dilayani kapan pun dia mau, ditemukan bahwa 27 orang (93.10\%) Mubaligh menyatakan setuju, dan 2 orang (6.90\%) menyatakan tidak setuju. Sementara 16 orang (100\%) Mubalighah menyatakan tidak setuju terhadap pernyataan ini. Hal ini berarti mayoritas Mubaligh berpendapat bahwa suami harus dilayani kapapun 
dia mau, bahkan seluruh Mubalighah menolak pernyataan tadi. Hal tersebut biasa disebabkan pemahaman terhadap ajaran agama (fikih) sebagai pemahaman yang cenderung patriarki.

Ditemukan bahwa 15 orang (51.72\%) Mubaligh menyatakan setuju terhadap pernyataan bahwa istri memiliki hak cerai, dan 14 orang (48.28\%) menyatakan tidak setuju terhadap pernyataan ini. Sementara 11 orang (68.75\%) Mubalighah setuju bila dikatakan istri memiliki hak cerai dari suaminya, dan 5 orang (31.25\%) menyatakan tidak memiliki hak cerai dari suaminya. Jadi, mayoritas baik Mubaligh maupun Mubalighah, menyatakan bahwa istri mempunyai hak cerai dari suaminya di kala suami tidak memenuhi kewajibannya. Sedangkan minoritas Mubaligh berpendapat bahwa istri tidak mempunyai hak cerai karena berpendapat bahwa talak hanya ada di tangan suami.

Mengenai seorang istri wajib mematuhi semua kata-kata dan perintah suami, ditemukan bahwa 9 orang mubaligh (31.04\%) menyatakan setuju, dan 20 orang (68.96\%) menyatakan tidak setuju. Sementara 12 orang (75\%) Mubalighah menyatakan setuju seorang istri harus mematuhi kata-kata dan perintah suaminya, dan 4 orang (25\%) menyatakan tidak setuju dengan pernyataan ini. Tampak terjadi perbedaan yang signifikan antara Mubaligh dan Muballighah. Mayoritas Mubaligh menyatakan bahwa istri tidak harus mematuhi seluruh perintah dan kata-kata suaminya, sebaliknya mayoritas Mubalighah (perempuan) berpendapat bahwa istri harus mematuhi setiap perintah dan kata-kata suami.

\section{Persepsi Mubaligh dan Mubalighah terhadap Peran Ganda}

Persepsi Muballigh dan Mubalighah terhadap peran ganda dilihat dari 6 (enam) kategori: tugas istri yang bekerja di luar rumah dan di dalam rumah, suami membantu pekerjaan rumah tangga, atau tugas istri.

Pengumpulan data terhadap indikator ini menunjukkan bahwa 17 orang (58.62\%) Mubaligh setuju bahwa istri yang bekerja di luar, pekerjaan rumah tangga sepenuhnya menjadi tugas dan tanggung jawab istri; dan 12 orang (41.38\%) Mubaligh tidak setuju dengan pernyataan ini. Sementara seluruh Mubalighah, 16 orang (100\%), tidak setuju bila dikatakan bahwa sekalipun istri bekerja di luar, pekerjaan rumah tangga tetap menjadi tugas dan tanggung jawab istri. Jadi, mayoritas Mubaligh berpendapat bahwa istri yang bekerja di luar rumah harus bertanggung jawab penuh dengan pekerjaan dan tugas rumah tangga. Sedangkan Mubalighah berpendapat bahwa pekerjaan dan tugas di rumah tangga seluruhnya tidak menjadi tanggung jawab istri, karena akan terjadi beban ganda terhadap istri.

Mengenai pernyataan bahwa membantu pekerjaan istri adalah hal yang memalukan, sebanyak 5 orang (17.24\%) Mubaligh menyatakan setuju, dan 24 orang (82.76\%) menyatakan tidak setuju. Seluruh Mubalighah (perempuan) menyatakan tidak setuju. Hal ini berarti bahwa di kalangan Mubaligh masih ada yang berpendapat bahwa suami 
yang membantu tugas istri adalah hal yang memalukan. Hal tersebut karena budaya mereka menganggap tidak layak kalau suami turut mengerjakan pekerjaan rumah tangga.

Terhadap pernyataan bahwa laki-laki tugasnya hanya mencari nafkah saja, ditemukan bahwa 9 orang (31.04\%) Mubaligh menyatakan setuju, dan 20 orang (68.96) Mubaligh menyatakan tidak setuju dengan pernyataan ini. Seluruh Mubalighah, 16 orang (100\%), menyatakan tidak setuju bila dikatakan pekerjaan suami hanya mencari nafkah saja. Mayoritas Mubaligh dan seluruh Mubalighah tidak setuju kalau tugas suami hanya mencari nafkah saja walaupun masih ada Mubaligh yang berpendapat bahwa memang tugas suami hanya mencari nafkah.

Mengenai tugas istri mengasuh anak dan mengurus rumah tangga tidak bisa digantikan oleh suami, ditemukan bahwa 6 orang (20.69\%) Mubaligh menyatakan setuju, dan 23 orang (79.31\%) Mubaligh menyatakan tidak setuju. Sedangkan 3 orang (18.75\%) Mubalighah menyatakan setuju bahwa tugas istri mengasuh anak dan mengurus rumah tangga tidak bisa digantikan oleh suami, dan 13 orang (81.25\%) menyatakan tidak setuju. Mayoritas Mubaligh berpendapat bahwa tugas mengasuh anak dan mengurus rumah tangga bisa digantikan oleh laki-laki (suami).

Ditemukan bahwa 22 orang (75.86\%) menyatakan setuju bahwa perempuan boleh bekerja asal tidak meninggalkan tanggung jawab mengurus rumah tangga, dan 7 orang (24.14\%) menyatakan tidak setuju dengan pernyataan ini. Sedangkan 12 orang (75\%) Mubalighah menyatakan setuju perempuan bekerja di luar rumah asal tidak meninggalkan pekerjaan rumah tangga, dan 4 orang (25\%) menyatakan tidak setuju dengan pernyataan ini. Mayoritas Mubaligh berpendapat bahwa istri boleh bekerja di luar rumah asal tidak meninggalkan pekerjaan rumah tangganya. Hal ini jelas menunjukkan bahwa domestik adalah tanggung jawab perempuan sehingga memungkinkan beban ganda.

Berkaitan dengan pernyataan pekerjaan rumah tangga hanya pantas dilakukan oleh perempuan (istri), 8 orang (27.59\%) Mubaligh menyatakan setuju, dan 21 orang (72.41\%) menyatakan tidak setuju. Sementara seluruh Mubalighah, 16 orang (100), menyatakan tidak setuju bila dikatakan pekerjaan rumah tangga hanya pantas dikerjakan oleh perempuan. Dari data tersebut menunjukkan bahwa mayoritas Mubaligh dan Mubalighah tidak sependapat dengan pernyataan tersebut karena pernyataan tersebut hanya akan melanggengkan peran domestik perempuan. Dari sini tampak telah ada kesadaran gender (peran ganda) di kalangan Mubaligh dan Mubalighah.

\section{Persepsi Mubaligh dan Mubalighah terhadap Subordinasi}

Persepsi Mubaligh dan Mubalighah terhadap subordinasi dilihat dari lima poin: pengambilan keputusan dalam rumah tangga, pendidikan, pemimpin organisasi, kecerdasan dan jabatan perempuan lebih tinggi dari laki-laki. Dari indikator ini, ditemukan bahwa 20 orang (68.96 \%) Mubaligh setuju bahwa istri harus dilibatkan dalam pengambilan 
keputusan dalam rumah tangga, dan 9 orang (31.04\%) menyatakan tidak setuju. Sementara seluruh muballighah, 16 orang (100\%), menyatakan setuju istri harus dilibatkan dalam keputusan rumah tangga oleh suaminya. Jadi, mayoritas Mubaligh berpendapat bahwa istri harus dilibatkan dalam pengambilan keputusan di keluarga.

Mengenai pernyataan bahwa pendidikan laki-laki seharusnya lebih tinggi dari perempuan, ditemukan bahwa 17 orang (58.62\%) Mubaligh menyatakan setuju, dan 12 orang (41.38\%) menyatakan tidak setuju. Sedangkan seluruh Mubalighah sebanyak 16 orang (100\%) menyatakan tidak setuju bahwa pendidikan laki-laki harus lebih tinggi dari perempuan. Lebih banyak Mubaligh (1aki-laki) yang berpendapat bahwa laki-laki seharusnya berpendidikan lebih tinggi dari perempuan.

Pernyataan bahwa pemimpin organisasi harus seorang laki-laki, ditemukan bahwa 10 orang (34.48\%) Mubaligh menyatakan setuju, dan 19 orang (65.52\%) menyatakan tidak setuju. Sedangkan seluruh Mubalighah, 16 orang, menyatakan tidak setuju bila pemimpin organisasi harus seorang laki-laki. Lebih banyak Mubaligh yang berpendapat bahwa pimpinan organisasi tidak harus laki-laki.

Ditemukan bahwa 29 orang (100\%) Mubaligh menyatakan tidak setuju bila dikatakan bahwa laki-laki selalu lebih cerdas dari perempuan. Sedangkan 4 orang (25\%) Mubalighah menyatakan setuju, dan 12 orang (75\%) Mubalighah menyatakan tidak setuju bila dikatakan laki-laki selalu lebih cerdas dari perempuan. Seluruh Mubaligh berpendapat bahwa laki-laki tidak harus lebih cerdas dari laki-laki, tetapi ada sebagian kecil Mubalighah yang berpendapat bahwa laki-laki memang lebih cerdas dari perempuan.

Ditemukan juga bahwa 20 orang (68.96\%) Mubaligh menyatakan setuju terhadap pernyataan tidak suka kalau perempuan menduduki jabatan lebih tinggi dari laki-laki, dan 9 orang (31.04\%) menyatakan tidak setuju dengan pernyataan ini. Sementara 10 orang (62.5\%) Mubalighah juga menyatakan tidak setuju bila perempuan menduduki jabatan lebih tinggi dari laki-laki, dan 6 orang menyatakan tidak masalah bila perempuan menduduki jabatan lebih tinggi dari laki-laki.

\section{Penutup}

Dari pembahasan di atas dapat disimpulkan bahwa persepsi Mubaligh dan Mubalighah terhadap keadilan dan kesetaraan gender belum sepenuhnya tepat. Masih ada pemahaman yang salah terhadap ajaran agama, sehingga memunculkan pula persepsi yang salah terhadap keadilan dan kesetaraan gender dalam masalah yang disentuh ajaran agama tersebut. Kemudian, tidak ada konsistensi dalam persepsi mereka. Dengan kata lain, pendapat yang cenderung mengesankan telah ada kesadaran gender pada satu tema di dalam satu indikator, ternyata tidak sejalan dengan tema lain yang ada dalam indikator yang sama, sehingga muncul pendapat yang kontra misalnya mayoritas mereka setuju bila seorang pemimpin tidak harus laki-laki, tapi mereka juga tidak setuju bila seorang perempuan menduduki 
jabatan lebih tinggi dari laki-laki. Hasil penelitian ini selanjutnya menunjukkan adanya hubungan antara persepsi Mubaligh dan Mubalighah dengan disposisi jenis kelamin, di mana jenis kelamin perempuan lebih cenderung menunjukkan keberpihakannya kepada perempuan, sedangkan dari pihak laki-laki (50\%) masih menunjukkan bias gender.

Berdasarkan kesimpulan di atas, sejumlah saran penting diajukan. Pertama, berdasarkan hasil persepsi terhadap keadilan dan kesetaraan gender di kalangan Mubaligh dan Mubalighah yang ada di Sumatera Utara khususnya di pinggiran kota Medan, memberi indikasi bahwa keadilan dan kesetaraan gender di kalangan Mubaligh dan Mubalighah belum sesuai dengan apa yang diharapkan. Karena itu disarankan kepada pihak pemerintah agar kembali merumuskan langkah-langkah kebijakan untuk mensosialisaikan keadilan dan kesetaraan gender di kalangan masyarakat secara umum dan di kalangan Mubaligh dan Mubalighah secara khusus. Hal ini perlu dilakukan mengingat pentingnya kedudukan Mubaligh dan Mubalighah di tengah-tengah masyarakat adalah corong di tengah masyarakat, khususnya masyarakat Muslim. Fungsi mereka menyampaikan ajaran dan pemahaman agama terhadap masyarakat. Kedua, Mubaligh dan Mubalighah adalah salah satu produk lembaga pendidikan, sehingga disarankan kepada pemerintah juga bekerjasama dengan lembaga pendidikan dimaksud untuk melakukan sosialisasi keadilan dan kesetaraan gender di lembagalembaga pendidikan yang notabene menghasilkan Mubaligh dan Mubalighah. Disarankan kepada seluruh Perguruan Tinggi Keagamaan Islam Negeri (PTKIN) melalui Pusat Studi Wanita (PSW) dan Pusat Studi Gender dan Anak (PSGA) untuk lebih serius merancang program kegiatan yang terencana untuk melakukan sosialisasi keadilan dan kesetaraan gender di kalangan Mubaligh dan Mubalighah. Lebih awal perlu dilakukan sosialisasi keadilan dan kesetaraan gender di kalangan mahasiswa PTKIN yang juga memiliki peluang dan kesempatan menjadi Mubaligh dan Mubalighah di masa-masa mendatang.

\section{Pustaka Acuan}

Ahmed, Leila. Wanita dan Gender dalam Islam, terj. M.S. Nasrulloh. Jakarta: Lentera, 2000. Al-Zuhaili, Wahbah. Nizham al-Islâm. Beirut: Dâr Qutaibah, 1993.

Anshori, Dadang S. Membincangkan Feminisme. Bandung: Pustaka Hidayah, 1997.

As-Sabuni, Muhammad 'Ali. Rawa’i al-Bayân li Tafsîr Âyât A $\underline{h} k a ̂ m$ min al-Qur'ân. Damaskus: Maktabah al-Ghazâlî, 1981 M/1391 H.

Budiaman, Kris. Feminografi. Yogyakarta: Pustaka Pelajar, 1999.

Chaplin, C.P. Kamus Lengkap Psikologi, terj. Kartini Kartono. Jakarta: RajaGrafindo Persada, 1981.

Ciciek, Farha. Ikhtiar Mengatasi Kekerasan dalam Rumah Tangga. Jakarta: LKAJ, PSP. The Asia Foundation, 1999.

Departemen Pendidikan dan Kebudayaan. Kamus Besar Bahasa Indonesia. Jakarta: Balai Pustaka, 1995. 
MIQOT Vol. XL No. 1 Januari-Juni 2016

Djohani, Rianingsih. Dimensi Gender dalam Pengembangan Program Secara Partisipasif Bandung: Studio Driya Media. 1996.

Drever, James. A Dictionary of Psychology. England: Penguin Books, 1974.

Fakih, Mansour, et.al. Membincang Feminisme (Diskursus Gender Perspektif Islam). Surabaya: Risalah Gusti, 2000.

Fakih, Mansour. Analisis Gender dan Transformasi Sosial. Yogyakarta: Pustaka Pelajar, 1999.

Fayumi, Badriyah, et al. Keadilan dan Kesetaraan Gender Perspektif Islam. Jakarta: Tim Pemberdayaan Perempuan Bidang Agama, 2001.

Fishbein, Martin, dan Icek Ajzen. Belief Attitude, Intention and Bahavior: an Introduction to Theory and Research. Massachusetts: Addison Wesley Publishing Company, 1975.

Kolibonso, R.S. "Kekerasan dalam Rumah Tangga Sebagai Pelanggaran Hak Asasi Manusia," dalam A.S. Luhalima (ed.) Pemahaman terhadap Bentuk-bentuk Kekerasan terhadap Perempuan dan Alternatif Pemecahannya. Jakarta: Kelompok Kerja "Convention Watch," Pusat Kajian Wanita Fewleral, 2000.

Mosse, Julia Cleves. Gender dan Pembangunan. Yogyakarta: Pustaka Pelajar, 1996.

Oakley, Ann. Sex, Gender and Society. New York: Yale University Press, 1972.

Rahz, Muhammad Hidayat (ed.). Perempuan yang Menuntun. Bandung: Ashoka Indonesia, 2000 .

Ridha, Muhammad Rasyid. Tafsîr al-Manar, Juz V. Beirut: t.p., t.t.

Salim, Peter dan Yenni Salim. Kamus Bahasa Indonesia Kontemporer. Jakarta: Modern English Press, t.t.

Sarwono, Sarlito Wirawan. Pengantar Umum Psikologi. Jakarta: Bulan Bintang, 1982.

Subhan, Zaitunah. Tafsir Kebencian (Studi Bias Gender dalam Tafsir Qur'an). Yogyakarta: LKiS, 1999.

Thalib, Muhammad. Dilema Wanita Karir. Yogyakarta: Wihdah Press, 1999.

Umar, Nasaruddin. Argumen Kesetaraan Jender Perspektif al-Qur'an. Jakarta: Paramadina, 1999.

Wemer, N.A. M. Ar. Zahn \& R.S. Sagi. Violence Pattern, Causes, Public Policy. New York: Harcourt Brace Jovanovich, t.t.

Yamani, Mai (ed.). Feminisme dan Islam. Bandung: Yayasan Nuansa Cendikia, Yayasan Adikarya IKAPI dan The Ford Foundation, 2000.

Zamakhsyari. Tafsîr al-Kasyaf. Beirut: Dâr al-Kutub al-'Ilmiyyah, t.t. 